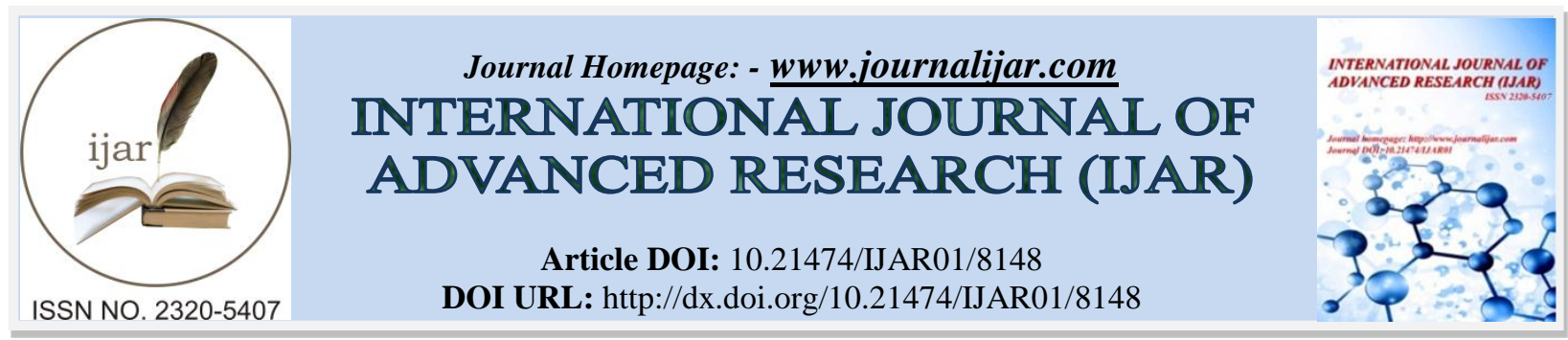

RESEARCH ARTICLE

\title{
THE REQUIREMENTS FOR TRANSFER PRICING DOCUMENTATION WITHIN THE FRAME OF BEPS ACTION PLANS.
}

Ceyda Kukrer.

\section{Manuscript Info}

\section{Manuscript History}

Received: 04 October 2018

Final Accepted: 06 November 2018

Published: December 2018

Keywords:

Transfer pricing, OECCD Transfer Pricing Guidelines, BEPS, BEPS Action Plan 13th.

\begin{abstract}
As one of the pioneers and major contributors to the Base Erosion and Profit Shifting (BEPS) initiative of the Organisation for Economic Co-operation and Development (OECD) and G-20 countries, on 16 March 2016, the Revenue Administration website has 3 Serial Transfer Pricing in Turkey. The major one has been the introduction of the concepts of Master File and Country by Country $(\mathrm{CbC})$ reporting in the Turkey's transfer pricing (TP) regulations in line with BEPS Action Plan 13. By BEPS Action Plan 13th, a series of amendments and updates were made on the 5th Chapter of the OECD Transfer Pricing Guidelines concerning document. In this article, the existing transfer pricing regulations will be discussed with the guidance of the the articles of the BEPS Action Plan 13th.
\end{abstract}

Copy Right, IJAR, 2018,. All rights reserved.

\section{Introduction:-}

Commercial, economic activities has made remarkable progress in an extremely fast globalizing world. The fact that the tax systems of the countries did not make the same progress in the face of this dizzying development. On the other hand e-commerce volume has a large share in the global economy with technological advances has caused the countries to exceed the controllable level with their own tax legislation. Especially after the 2008 crisis, the need for tax revenues of the countries increased, this resource required to be managed more efficiently.

Action 13 of the Action Plan on Base Erosion and Profit Shifting (BEPS Action Plan, OECD, 2013) requires the development of "rules regarding transfer pricing documentation to enhance transparency for tax administration, taking into consideration the compliance costs for business. The rules to be developed will include a requirement that MNEs provide all relevant governments with needed information on their global allocation of the income, economic activity and taxes paid among countries according to a common template".

On 16 March 2016, the Draft Communiqué on Disguised Profit Distribution via Serial No. 3 Transfer Pricing was published on the website of the Revenue Administration in Turkey. The Communiqués in the Communiqué present additional explanations on the issues that are open to interpretation, eliminating the existing shortcomings, and correcting the wrong examples; arrangements are introduced for the inclusion of new documentation rules, Cost Contribution Agreements and additional comparability factors within the scope of the legislation.

\section{New transfer pricing documentation rules:-}

The action plan 13, which establishes one of the Action Plan for Base Erosion and Profit Shifting (BEPS) published by the OECD, has made some changes and updates to the section on certification of OECD's Transfer Pricing Guide. This action plan introduces two new certification obligations in addition to the obligation to prepare existing annual transfer pricing reports. The proposed standardized three-tiered approach to transfer pricing documentation for Commercial, economic activities has made remarkable progress in an extremely fast globalizing world. The fact that the tax systems of the countries did not make the same progress in the face of this dizzying development. On the other hand e-commerce volume has a large share in the global economy with technological advances has caused the

\section{Corresponding Author:-Ceyda Kukrer.}


countries to exceed the controllable level with their own tax legislation. Especially after the 2008 crisis, the need for tax revenues of the countries increased, this resource required to be managed more efficiently. (MNE) groups has replaced the former Chapter 5 of the OECD Transfer Pricing Guidelines in July 2017 and should consist of the following: (i) a Master File, (ii) a Local File, and (iii) Country-by-Country Reporting (CbCR).

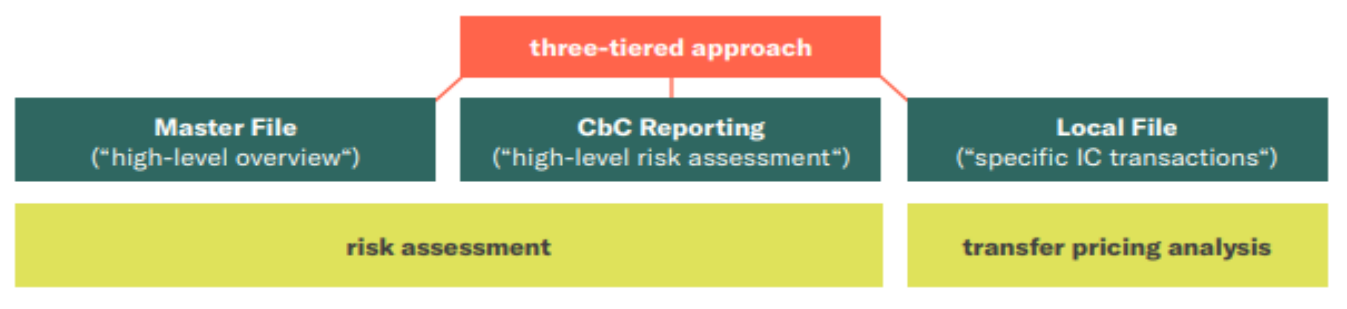

Master file; the main certification for transfer pricing will include some information and documents standardized for all members of the multinational group of companies.

Local file; the country-specific certification is complementary to the main certification and in this context, the information and documents requested from the enterprises will be prepared primarily to support the main documentation.

Country by country $(\mathrm{CbC})$ : The revenue generated by the multinational corporations and the consolidated revenue in excess of $€ 750$ million, it is a report form that contains information such as taxes.

OECD regulations are not directly binding regulations of the Member States. However, if the member states make regulations in this direction, obligations arise for the taxpayers operating in that country. In this context, in our country, if the tax administration makes arrangements in line with this action plan, however, new certification obligations will arise.

Transfer pricing certification obligations in the Draft Communiqué:-

The explanations regarding the possible future certification requirements are given below, taking into account the explanations in the Communique V3 of the OECD transfer pricing guideline updated with the BEPS Action Plan number 13 and the explanations in the Communiqué No: 3 transfer pricing.

\section{Master file:-}

The explanations regarding the obligation to prepare master files according to the Communiqué No. 3 of Transfer Pricing published below are as follows:

The Master File is expected to provide an overview or blue print of an Multinational Enterprises ("MNEs") group's global business model, specifically covering the following aspects - (a) organisational structure, (b) description of the various businesses, (c) intangibles used in the businesses, (d) intercompany financial transactions, and (e) financial and tax positions.

In March 2016, the Turkish tax administration announced a new draft "General Communiqué numbered 3 on Disguised Profit Distribution through Transfer Pricing". As a result, the Master File, the Local File and the CbCR should have been implemented by the end of 2017. If the communiqué enters into force, the relevant legislation will comply with the OECD principles.

Thresholds determine as the Master File will be prepared by corporate taxpayers whose assets and net revenue exceed TRY 250 million. Deadline for the preparation: By the end of the second month (end of June) following the submission date of the corporate income tax return ; the deadline may differ for deviating fiscal years. Submission deadline: Not specified yet; probably within two months after the expiration of the deadline for filing the CIT return. The effects of the new arrangements to the taxpayer the rate in excess of TRY 250 million when considering the sheer number of taxpayers resident in Turkey is expected to bring a huge liability for taxpayers group of the master file. In addition, this obligation is especially bring a master file have not been the embodiment of an additional 
preparation liability on the company resident in Turkey by multinational country administration where the ultimate parent company of the business group in which the taxpayer in Turkey.

\section{Local file:-}

Every entity with tax residency in Turkey and executing cross-border transactions is required to prepare the Local File. The Local File includes the preparation of three sets of documents:

1. Annual transfer pricing report;

2. Transfer pricing form;

3. New transaction-based transfer pricing form.

Thresholds determine as no threshold for preparing the annual transfer pricing report; -Transfer pricing form: A total transaction volume of more than TRY 30,000. Turkish taxpayers whose assets and net revenue exceed TRY 100 million are required to prepare the new transaction-based transfer pricing form. Deadline for the preparation: Within the deadline for filing the CIT return. Submission deadline: Within 15 days after receiving a request from the tax administration.

\section{Country-by-Country Reporting :-}

The Guidance on Country-by-Country Reporting states that: [h]eightened scrutiny of transfer pricing issues by tax administrations has resulted in a significant increase in compliance costs for taxpayers. Nevertheless tax administrations often find transfer pricing documentation to be less than fully informative and not adequate for their tax enforcement and risk assessment needs.

Within this context, three objectives have been determined in this Action. These objectives are as follows:

1. allowing the tax authorities to properly assess transfer pricing risk. This objective is related to ensuring that tax authorities have relevant and reliable transfer pricing documentation in order to properly assess transfer pricing risk;

2. allowing taxpayers to assess their compliance with the arm's length principle. The taxpayer's consideration of available data and analysis of consistency with the arm's length principle is also critical in providing assurance to tax administrations as regards the taxpayer's assessment; and

3. affording tax administrations with useful information for transfer pricing audits. Tax administrations need appropriate transfer pricing documentation in order to conduct thorough audits. The Guidance indicates that it is clear that tax administrations must have the ability to obtain, within a reasonable period, all relevant documents and information in the taxpayer's possession.

Threshold determine as ultimate parent companies of multinational groups whose annual consolidated group revenue exceeded TRY 2.37 million in the previous year. Submission deadline for the Country-by-Country Reporting is within 12 months after the end of the reporting fiscal year. Surrogate filing and secondary filing is not defined in the draft. Turkey is not yet a signatory of the Multilateral Competent Authority Agreement on the Exchange of CbCR (the "CbC MCAA"). OECD's XML format for submission has been implemented.

\section{Conclusion:-}

On 16 March 2016, the Revenue Administration website has 3 Serial Transfer Pricing in Turkey. The Revenue Administration has already requested that the opinions and suggestions on the development, modification or contribution of this draft be communicated to them. The Revenue Administration makes important arrangements for compliance with international legislation with the Draft Communiqué and provides additional explanations for some areas in the existing regulations in order to overcome some hesitations in implementation. 


\section{References:-}

1. OECD, Discussion Draft on Transfer Pricing Documentation and CbC Reporting (OECD 2014), International Organizations' Documentation IBFD

2. Ramazan Biçer and Mehmet Erginay, "Turkish Perspective on OECD Action Plan on Base Erosion and Profit Shifting" Internatıonal Transfer Pricing Journal January/FEBRUARY 2015

3. Rodl and Partner, OECD Master File-concept and CbC Reporting - national implementation.

4. 1 April 2018. https://www.roedl.com/de-de/de/themen/documents/oecd-cbc-masterfile-implementierungenglisch.pdf

5. Çok uluslu işletmeler ve Vergi idareleri Transfer Fiyatlandırması rehberi, OECD Yayınları 2010

6. 1 Seri numaralı Transfer Fiyatlandırması Tebliği, Resmi Gazete Tarihi: 18/11/2007. Resmi Gazete No:26704

7. Metin Duran "BEPS Eylem Planları Çerçevesinde Transfer Fiyatlandırması ile ilgili Yeni Belgelendirme Yükümlülükleri", Vergi Sorunları Dergisi, Sayı: 339, Aralık 2016. 